\title{
Non-residential water demand model validated with extensive measurements and surveys
}

\author{
E. J. Pieterse-Quirijns ${ }^{1}$, E. J. M. Blokker ${ }^{1}$, E. van der Blom ${ }^{2}$, and J. H. G. Vreeburg ${ }^{1,3}$ \\ ${ }^{1}$ KWR Watercycle Research Institute, P.O. Box 1072, 3430 BB Nieuwegein, the Netherlands \\ ${ }^{2}$ Uneto-VNI, P.O. Box 188, 2700 AD Zoetermeer, the Netherlands \\ ${ }^{3}$ Delft University of Technology, Faculty of Civil Engineering, P.O. Box 5048, 2600 GA Delft, the Netherlands
}

Correspondence to: E. J. Pieterse-Quirijns (ilse.pieterse@kwrwater.nl)

Received: 13 July 2012 - Published in Drink. Water Eng. Sci. Discuss.: 24 August 2012

Revised: 21 August 2013 - Accepted: 14 October 2013 - Published: 31 October 2013

\begin{abstract}
Existing Dutch guidelines for the design of the drinking water and hot water system of nonresidential buildings are based on outdated assumptions on peak water demand or on unfounded assumptions on hot water demand. They generally overestimate peak demand values required for the design of an efficient and reliable water system. Recently, a procedure was developed based on the end-use model SIMDEUM to derive design-demand-equations for peak demand values of both cold and hot water during various time steps for several types and sizes of non-residential buildings, viz. offices, hotels and nursing homes. In this paper, the design-demand-equations are validated with measurements of cold and hot water patterns on a per second base and with surveys. The good correlation between the simulated water demand patterns and the measured patterns indicates that the basis of the design-demand-equations, the SIMDEUM simulated standardised buildings, is solid. Surveys were held to investigate whether the construction of the standardised buildings based on the dominant variable corresponds with practice. Surveys show that it is difficult to find relationships to equip the standardised buildings with users and appliances. However, the validation proves that with a proper estimation of the number of users and appliances in only the dominant functional room of the standardised buildings, SIMDEUM renders a realistic cold and hot water diurnal demand pattern. Furthermore, the new design-demand-equations based on these standardised buildings give a better prediction of the measured peak values for cold water flow than the existing guidelines. Moreover, the new design-demand-equations can predict hot water use well. In this paper it is illustrated that the new design-demand-equations lead to reliable and improved designs of building installations and water heater capacity, resulting in more hygienic and economical installations.
\end{abstract}

\section{Introduction}

Non-residential users have a significant impact on drinking water demand and exhibit a diurnal pattern which can be completely different from residential users (Loureiro et al., 2010; Blokker et al., 2011). In the Netherlands, nonresidential water demand amounts to approximately $28 \%$ of the total distributed water. Small-scale business users, defined as buildings using less than $10000 \mathrm{~m}^{3} \mathrm{yr}^{-1}$, use $12 \%$ of the total distributed water. Small-scale users include shops, hotels, restaurants, schools, offices, health care institutions, and campsites. Large-scale business users are defined as cus- tomers that use more than $10000 \mathrm{~m}^{3} \mathrm{yr}^{-1}$ and are mainly concerned with industrial activities (Baggelaar and Geudens, 2008). Despite the significant impact of non-residential users, limited information relating to their expected water demand exists. It is known that the behaviour of the type of users varies: an office employee, a hotel guest, a cleaner, kitchen personnel and a patient in a nursing home exhibit variability in demand, in time of demand, in frequency of demand, etc. Some users have similar behaviour to residential users, whereas other have completely different behaviour (Blokker et al., 2011; Pieterse-Quirijns et al., 2009). Studies on water consumption in commercial and industrial sectors, 
Table 1. Old guidelines for maximum momentary flow of cold water in various non-residential buildings (Scheffer, 1994).

\begin{tabular}{ll}
\hline Type of non-residential building & Relation for peak demand $\mathrm{MMF}_{\text {cold }}\left(\mathrm{L} \mathrm{s}^{-1}\right)$ \\
\hline Office - toilets with cistern & $1.464+0.0019^{*}$ (number of employees) \\
Office - toilets with flushing valve & $2.603+0.0031^{*}$ (number of employees) \\
Hotel business & $q \sqrt{ } n+40 \%{ }^{1}$ \\
Hotel tourist & $q \sqrt{ } n+70 \%$ \\
Retirement home & $1.177+0.0092^{*}$ (number of beds) \\
Nursing home & $2.257+0.0130^{*}$ (number of beds) \\
\hline
\end{tabular}

ad $^{1}: q \sqrt{ } n$-method: $q \sqrt{ } n=0.083 \cdot \sqrt{\Sigma} \mathrm{LU}, \mathrm{LU}$ is number of loading-units. Every type of tapping point is credited with loading-units equal to $0.083 \mathrm{~L} \mathrm{~s}^{-1}\left(300 \mathrm{~L} \mathrm{~h}^{-1}\right)$. A toilet cistern is, for example, typically $0.25 \mathrm{LU}$.

i.e. hotels and mining residences, show that water consumption is influenced by cultural and social norms (Rankin and Rousseau, 2006). Water consumption not only varies between countries but also between comparable buildings in the same country. It is influenced by many factors, such as season and occupancy (Rankin and Rousseau, 2006; Barberán et al., 2013; Cobacho et al., 2005). In hotels, a significant part of water consumption is due to the needs of guests in their rooms. Therefore, it depends on occupancy rates, kind of facilities, habits of guests and personnel (Cobacho et al., 2005).

This lack of information creates problems during the design of water infrastructure and in the management of water demand (Ilemobade et al., 2010). To guarantee a high expected water demand, pipe diameters in distribution networks are generally oversized. However, it is understood that this overcapacity causes water quality problems, especially discolouration (Vreeburg, 2007). This lack of information also complicates the design of drinking water systems inside buildings as well as the optimal selection of the type and capacity of water heating systems. Badly designed systems can cause stagnant water with health risks, and are less energy efficient and therefore more expensive to operate. The occurrence of Legionella in non-residential buildings is an internationally recognised problem (Van der Kooij et al., 2005) that is related to too high temperatures in the cold water system or too low temperatures in the hot water system, that can be caused by badly designed hot water circulation systems.

For the design of the drinking water distribution system outside as well as inside buildings, understanding the peak value of the total water demand, the instantaneous peak demand or maximum momentary flow $\left(\mathrm{MMF}_{\text {cold }}\right)$, is essential (Loureiro et al., 2010; Blokker and Van der Schee, 2006). In the Netherlands, existing guidelines provide the $\mathrm{MMF}_{\text {cold }}$ for non-residential buildings of various types and sizes (Table 1). These guidelines are based on measurements carried out between 1976 and 1980. Total water demand was measured with small time step during several weeks in buildings of different sizes (Werkgroep momentane waterverbruiken, 1985). Presumably, the guidelines are no longer suitable for modern non-residential buildings, that have altered consider- ably in the past decades with respect to appliances and number and behaviour of users. For example, rest rooms are now equipped with water saving plumbing fixtures and urinals; in offices the coffee lady has been replaced with machines. Moreover, the working habits have changed, with more flexibility in working hours, with open-plan offices and a difference in ratio of men and women and an aim at maximum occupancy. Hotels are more luxurious and in some cases are extended with facilities for a conference or theatre. Nursing homes have changed in the recent years, aiming at small-scale services and residents' independency. The residents have expectations concerning privacy and continuing their personal way of life, resulting in qualitative enhancement of facilities and equipment to improve quality of life. The outlined problems, caused by overcapacity, and new developments in Legionella control, suggest that the existing guidelines do not give an accurate insight into peak water demand.

Hot water consumption profiles have a significant influence on the hot water system design (Rankin and Rousseau, 2006). Understanding hot water demand is essential to select the correct type of water heater as well as the design capacity of the hot water device. In addition to the peak demand of hot water, i.e. maximum momentary flow $\left(\mathrm{MMF}_{\text {hot }}\right)$, the hot water use (HWU) in different time periods is required for the choice and design of hot water devices. The desired time period depends on the type of selected water heater system (Scheffer, 1994). For the characteristic values of hot water demand $\left(\mathrm{MMF}_{\text {hot }}\right.$ and $\left.\mathrm{HWU}\right)$ there are no national and international guidelines, similar to those for cold demand in Table 1. Suppliers of heating systems use their own company specific guidelines.

Because of the described problems with the existing guidelines and because no guidelines exist for the hot water demand, new models for characteristic values of cold and hot water for non-residential buildings are required. In 2010, a procedure was developed to derive design-demand-equations for the peak demand values of both cold and hot water for various types of non-residential buildings, i.e. offices, hotels and nursing homes (Pieterse-Quirijns et al., 2010). The design-demand-equations are based on water demand 
Table 2. Functional rooms and the type of user who take water in the functional rooms in three categories of non-residential buildings, office, hotel and nursing home.

\begin{tabular}{llll}
\hline \multirow{2}{*}{ Functional room } & \multicolumn{3}{c}{ Type of users (and reason for variable occupancy) } \\
\cline { 2 - 4 } & office & hotel & nursing home \\
\hline Meeting area & $\begin{array}{l}\text { Employees (fulltime/part-time } \\
\text { working), visitors }\end{array}$ & $\begin{array}{l}\text { Guests (meeting, conference, theatre), } \\
\text { employees }\end{array}$ & Visitors, employees \\
Lodging & - & Hotel guests (tourists, business people) & Residents \\
Restaurant & Kitchen personnel & Kitchen personnel & Kitchen personnel \\
Fitness room & Employees using the fitness room & Hotel guests using the fitness room & - \\
Technical/other & \multicolumn{2}{c}{ Number of buckets filled for cleaning, washing machines, ... } \\
\hline
\end{tabular}

patterns simulated by SIMDEUM, an end-use model which simulates residential and non-residential water demand patterns (Blokker et al., 2011). In the procedure, SIMDEUM simulates diurnal water demand patterns, for a specific nonresidential building with a certain value of its dominant variable. This dominant variable characterises the size of a building, such as the number of employees in an office or the number of beds in a nursing home. A crucial part of the procedure is the standardisation of each type of building, meaning that for a specific value of the dominant variable, a building is constructed with the corresponding number and characteristics of appliances (like toilets, showers, etc.) and of users (like kitchen personnel, visitors, etc.). The relevant information is not easy to find, since there is much freedom in the design of sanitary installations. Moreover, the number and behaviour of present non-residential water users is barely known. In Sect. 2 of this paper, the background is described more extensively.

Before the SIMDEUM based design-demand-equations can be applied in practice and replace existing guidelines, they need to be validated. For the validation, measurements of cold and hot water diurnal demand patterns are required on a per second base for various buildings, to ensure an accurate determination of peak demands. This is the first time that water demand patterns (especially hot water demand) will be measured on such a small timescale in the Netherlands. The validation procedure consists of two steps.

In the first step, the assumptions of how to standardise buildings, on which the design-demand-equations are based, are validated with measurements and surveys. The validation step consists of two phases. Firstly, average simulated diurnal demand patterns of the standardised buildings are compared with measurements of cold and hot water patterns on a per second base for 6 different buildings. Secondly, surveys will show whether the construction of the standardised buildings based on the dominant variable corresponds with practice. When correspondence is established between standardised buildings and reality, in both predicted water demand patterns and construction of the building, the solid base of SIMDEUM based design-demand-equations is shown in a proof of concept, i.e. when the construction is reliable, the prediction of the expected cold and hot water demand in the building will be reliable.

In the second validation step, the outcome of the designdemand-equations is compared to the measured peak demand values of cold and hot water. When the basis is solid, this step shows that the derivation of the design-demand-equations is reliable.

This paper describes the validation of the SIMDEUM based design-demand-equations. Moreover, the consequences for design of distribution systems and heating systems are illustrated, by comparing resulting designs for pipe diameter, water meter and heaters from developed designdemand-equations, old guidelines and measured practical values.

\section{Background}

\subsection{Background of SIMDEUM for non-residential buildings}

SIMDEUM stands for "SIMulation of water Demand, an End-Use Model". It is a stochastic model based on statistical information of end uses, including statistical data on water appliances and users (Blokker et al., 2010). SIMDEUM's philosophy is that people's behaviour regarding water use is modelled, taking into account the differences in installation and water-using appliances. This means that in each building, whether it is residential or non-residential, the characteristics of the present water-using appliances and taps (i.e. flow rate, duration of use, frequency of use and the desired temperature) are considered as well as the water-using behaviour of the users who are present (i.e. presence, time of use, frequency of use).

SIMDEUM for non-residential water demand follows a modular approach. Each building is composed of functional rooms, characterised by its typical users and water using appliances (Table 2). The characteristics of the users and the appliances are different for each type of building and are extensively described by Blokker et al. (2011). With this approach, water demand patterns over the day for cold and hot water demand can be simulated for a specific non-residential 
Table 3. Different typologies of non-residential buildings within the categories offices, hotels and nursing homes and the dominant functional room and dominant variable in each category.

\begin{tabular}{|c|c|c|c|c|c|}
\hline \multirow[t]{2}{*}{ category } & \multicolumn{3}{|c|}{ typology } & \multicolumn{2}{|c|}{ dominant } \\
\hline & typology name & users & Discerning appliances & functional room & variable \\
\hline \multirow[t]{4}{*}{ office } & office A & $\begin{array}{l}\text { male:female }= \\
65 \%: 35 \%\end{array}$ & $\begin{array}{l}\text { toilet with } 6 \mathrm{~L} \text { cistern and } \\
\text { urinal }\end{array}$ & \multirow[t]{4}{*}{ meeting area } & \multirow[t]{4}{*}{$\begin{array}{l}\text { number of } \\
\text { employees }\end{array}$} \\
\hline & office B & $\begin{array}{l}\text { male }: \text { female }= \\
65 \%: 35 \%\end{array}$ & $\begin{array}{l}\text { toilet with flushing valve } \\
\text { and urinal }\end{array}$ & & \\
\hline & office $\mathrm{C}$ & $\begin{array}{l}\text { male }: \text { female }= \\
65 \%: 35 \%\end{array}$ & $\begin{array}{l}\text { toilet with } 6 \mathrm{~L} \text { cistern and } \\
\text { no urinal }\end{array}$ & & \\
\hline & office D & $\begin{array}{l}\text { male }: \text { female }= \\
90 \%: 10 \%\end{array}$ & $\begin{array}{l}\text { toilet with } 6 \mathrm{~L} \text { cistern and } \\
\text { urinal }\end{array}$ & & \\
\hline \multirow[t]{2}{*}{ hotel } & $\begin{array}{l}\text { business } \\
\text { (incl. conference) }\end{array}$ & business guests & 7 types of shower & \multirow[t]{2}{*}{ hotel rooms } & \multirow[t]{2}{*}{$\begin{array}{l}\text { number of hotel } \\
\text { rooms }\end{array}$} \\
\hline & tourist (incl. theatre) & tourist guests & 7 types of shower & & \\
\hline \multirow[t]{4}{*}{ nursing home } & A: individual room & $\begin{array}{l}\text { care needed } \\
\text { residents }\end{array}$ & $\begin{array}{l}3 \text { types of intensity of use } \\
\text { bedpan washer }\end{array}$ & \multirow[t]{4}{*}{$\begin{array}{l}\text { lodging and } \\
\text { meeting area }\end{array}$} & \multirow[t]{4}{*}{ number of beds } \\
\hline & $\begin{array}{l}\text { B: four persons per } \\
\text { room }\end{array}$ & $\begin{array}{l}\text { care needed } \\
\text { residents }\end{array}$ & $\begin{array}{l}3 \text { types of intensity of use } \\
\text { bedpan washer }\end{array}$ & & \\
\hline & $\begin{array}{l}\mathrm{C} \text { : combination of } \\
\text { single rooms and } \\
\text { four persons per } \\
\text { room }\end{array}$ & $\begin{array}{l}\text { care needed } \\
\text { residents }\end{array}$ & $\begin{array}{l}3 \text { types of intensity of use } \\
\text { bedpan washer }\end{array}$ & & \\
\hline & $\begin{array}{l}\text { D: self-contained } \\
\text { apartments/assisted } \\
\text { living }\end{array}$ & $\begin{array}{l}\text { independent } \\
\text { residents }\end{array}$ & & & \\
\hline
\end{tabular}

building. From these daily water demand patterns, the characteristic peak demand values of cold and hot water during various time steps can be derived. These characteristics form the basis for design guidelines.

\subsection{Background of SIMDEUM based design-demand- equations for non-residential buildings}

For three categories of small-scale non-residential buildings SIMDEUM based design-demand-equations were developed, viz. offices, hotels and nursing homes. These categories are selected based on the cooperation with the Dutch installation sector, where they were mostly interested in these buildings (Blokker et al., 2011). These categories are most often applied in practice. Moreover, they are characterised by a generalised construction or standardisation. This in contrast with, for example, a hospital or a prison, which are more specific and cannot be captured in a general approach. Within each category, different typologies of buildings were defined. The typologies can vary in types of appliances, like types of toilets, flow of showers, and in the type of users, like business or tourist hotel guests. In Table 3, the defined typologies within each category are presented. The definition of the typologies is arbitrary. In the presented various typologies, existing building types were used as reference, based on practical experiences given by Uneto-VNI, the Dutch association of installers.

The aim of the design-demand-equations is to predict the peak demand values $\left(\mathrm{MMF}_{\text {cold }}, \mathrm{MMF}_{\text {hot }}\right.$ and $\mathrm{HWU}$ in different time periods) for various types of offices, hotels and nursing homes of arbitrary size. The new design-demandequations predict the peak demand values as a function of a (dominant) variable. Blokker et al. (2011) presented a sensitivity analysis for SIMDEUM for non-residential water demand in each of the considered categories. The dominant variable was established from this sensitivity analysis. The dominant variable is the functional room or user in a building that contributes most to the pattern and total amount of water use in a building. In offices, the main contributor (80$90 \%$ ) to water demand is the meeting area with the toilets. The dominant variable for offices therefore is the number of employees that use the toilets. In hotels, the main contributor is the hotel rooms (app. 80\%) for hotels without conference and theatre facilities and without laundry. The dominant 
Table 4. Number of users and their water use probability in each functional room in a standardised office as function of the dominant variable, $x$ the number of employees.

\begin{tabular}{|c|c|c|c|c|c|c|}
\hline \multirow[t]{2}{*}{ Functional room } & \multirow[t]{2}{*}{ Type of user } & \multirow[t]{2}{*}{ Number of users } & \multicolumn{4}{|c|}{ Times of presence and water use probability in office* } \\
\hline & & & $t_{1}$ & $t_{2}$ & $t_{3}$ & $t_{4}$ \\
\hline Meeting area & $\begin{array}{l}\text { employees and } \\
\text { visitors }\end{array}$ & $\begin{array}{l}x \\
10 \% \cdot x\end{array}$ & 08:00 & $12: 15$ & 13:00 & $17: 00$ \\
\hline Restaurant & kitchen personnel & $0.0052 \cdot x+2.24$ & $08: 30$ & $12: 30$ & $13: 30$ & $15: 00$ \\
\hline Fitness room & employees using the fitness room & $1.5 \% \cdot x$ & $07: 30$ & - & - & $18: 30$ \\
\hline Technical/other & cleaners & $0.0265 \cdot x+0.027$ & $17: 00$ & - & - & $18: 30$ \\
\hline
\end{tabular}

${ }^{*} t_{1}$ is starting time of water use probability, $t_{4}$ is the end. $t_{2}$ and $t_{3}$ characterise a peak in water use probability (Blokker et al., 2011).

Table 5. Number of appliances in each functional room of a standardised office as function of the dominant variable, $x$ the number of employees.

\begin{tabular}{|c|c|c|c|c|}
\hline Functional room & Appliance & & $\begin{array}{l}\text { Number of appliances as function of } x \\
\text { (number of employees) }\end{array}$ & remarks \\
\hline \multirow[t]{5}{*}{ Meeting area } & toilet ladies & $\begin{array}{l}x \leq 300 \\
x>300\end{array}$ & $\begin{array}{l}x / 12 \\
x / 18\end{array}$ & $\begin{array}{l}\text { frequency }=4,60 \% \text { of flushes } \\
\text { use the water saving option }\end{array}$ \\
\hline & toilet gentleman & $\begin{array}{l}x \leq 300 \\
x>300\end{array}$ & $\begin{array}{l}x / 12 \\
x / 18\end{array}$ & $\begin{array}{l}\text { frequency }=1 \text {, no use of water } \\
\text { saving option }\end{array}$ \\
\hline & urinal & $\begin{array}{l}x \leq 300 \\
x>300\end{array}$ & $\begin{array}{l}x / 12 \\
x / 18\end{array}$ & frequency $=3$ \\
\hline & tap wash basin & $\begin{array}{l}x \leq 300 \\
x>300\end{array}$ & $\begin{array}{c}2 \cdot x / 12 \\
x / 18\end{array}$ & frequency $=4.5$ \\
\hline & coffee machine & & $0.0232 \cdot x+4.5$ & frequency $=8$ \\
\hline \multirow[t]{2}{*}{ Restaurant } & kitchen tap & & $0.0052 \cdot x+2.24$ & $\begin{array}{l}\text { frequency of usage depends on } \\
\text { number of kitchen personnel and } \\
\text { number of guests in the restaurant }\end{array}$ \\
\hline & $\begin{array}{l}\text { dish washer } \\
x: 0-500 \\
x: 501-1000 \\
x: 1001-1500\end{array}$ & & $\begin{array}{l}1 \\
2 \\
3\end{array}$ & \\
\hline Fitness room & shower & & $0.0132 \cdot x-0.49$ & with boundary condition $>0$ \\
\hline Technical/other & cold and hot water & & $0.0265 \cdot x+0.027$ & \\
\hline
\end{tabular}

variable for hotels is the number of rooms, which can be occupied by 1 or 2 guests, depending on the type of hotel. In nursing homes, the water use is not determined by a single dominant functional room. The washing of the residents and the toilet use of personnel and visitors all largely determine the water use. Since the number of personnel and visitors is determined by the number of beds (with all beds occupied), the latter is defined as the dominant variable. For each category the dominant functional room and the dominant variable are given in Table 3 .

The procedure to derive the design-demand-equations for the peak demand values of cold and hot water for nonresidential buildings is extensively described in PieterseQuirijns et al. (2010). For a specific value of the domi- nant variable, a standard building was constructed, i.e. each functional room is equipped with appliances and users. For this purpose, the number of appliances and users is established as a function of the dominant variable for each type of non-residential building. An example for a standardised office is given in Table 4 for the number of users and in Table 5 for the number of appliances. From 100 stochastic demand patterns simulated with SIMDEUM at different values of the dominant variable, the peak demand values were derived, i.e. maximum momentary flow (MMF) for total and hot water $\left(\mathrm{MMF}_{\text {cold }}\right.$ and $\left.\mathrm{MMF}_{\text {hot }}\right)$ and the maximum hot water use (HWU) during time periods of $10 \mathrm{~min}\left(\mathrm{HWU}_{10}\right)$, of $1 \mathrm{~h}\left(\mathrm{HWU}_{60}\right)$, of $2 \mathrm{~h}\left(\mathrm{HWU}_{120}\right)$ and of 1 day $\left(\mathrm{HWU}_{\text {day }}\right)$. The resulting design demand parameters were defined as the 
Table 6. Selected buildings for measurement of cold and hot water demand and the number of measured days and weekdays, to validate the developed design-demand-equations for offices, hotels and nursing homes.

\begin{tabular}{lllllllll}
\hline & \multicolumn{2}{c}{ category offices } & \multicolumn{2}{c}{ category hotels } & \multicolumn{3}{c}{ category nursing homes } \\
\hline $\begin{array}{l}\text { typology } \\
\text { office A }\end{array}$ & $\begin{array}{l}\text { number of } \\
\text { employees } \\
(x)\end{array}$ & $\begin{array}{l}\text { total days/ } \\
\text { weekdays }\end{array}$ & $\begin{array}{l}\text { typology: } \\
\text { business } \\
\text { hotel }\end{array}$ & $\begin{array}{l}\text { number of } \\
\text { hotel } \\
\text { rooms }(x)\end{array}$ & $\begin{array}{l}\text { total days/ } \\
\text { weekdays }\end{array}$ & $\begin{array}{l}\text { typology: } \\
\text { care needed } \\
\text { residents }\end{array}$ & $\begin{array}{l}\text { number of } \\
\text { beds }(x)\end{array}$ & $\begin{array}{l}\text { total days/ } \\
\text { weekdays }\end{array}$ \\
\hline office I & 255 & $47 / 33$ & $\begin{array}{l}\text { business } \\
\text { hotel I }\end{array}$ & 80 & $32 / 22$ & nursing home I & 124 & $36 / 26$ \\
\hline office II & 2000 & $34 / 24$ & $\begin{array}{l}\text { business } \\
\text { hotel II }\end{array}$ & 192 & $28 / 18$ & nursing home II & 260 \\
\end{tabular}

* One wing of nursing home II has its own boiler. The measured hot water use concerns 212 beds.

99-percentile of the 100 values of the different peak demand values. These peak demand values for several buildings could be described by simple linear relations as a function of the dominant variable. These linear relations form the designdemand-equations.

\section{Methodology}

\subsection{Methodology to measure cold and hot water demand of non-residential buildings}

For the measurements of cold and hot water demand an ultrasonic flow meter was used. The Proline Prosonic Flow meter is a clamp-on meter that can be installed without disturbing the water supply. Requirements for a reliable measurement are closely met, such as sensor distance dependent on pipe material characteristics and distances from bends and other appendages. To ensure an accurate measurement of peak demand, the logging frequency was set to $1 \mathrm{~s}$. The logging precision was $0.5 \%$. The water demand was measured during minimal 20 weekdays for hotels and nursing homes and 30 working days for offices.

In each category of non-residential users, two buildings were selected with different values of the dominant variable. It appeared to be very difficult to find suitable buildings for the measurements. Narrow installation environments, the presence of buffers in the hot water circulation system, not enough straight pipes to install the flow sensor with desired distance from fittings, such as valves, T-pieces, elbows, etc. were the most common issues. Moreover, it appeared that Dutch offices are seldom equipped with a collective hot water system. Therefore, the measurement of hot water was not possible, and the developed design-demand-equations for offices can only be validated on cold water use. Since the hot water use in offices is very small, this is not a problem. The selected buildings are given in Table 6. During the measurements, full occupation was aimed for. However, this was difficult to achieve for the two hotels. The occupation varied between $4-100 \%$ during weekdays.
3.2 Methodology validation step 1: validation of how to standardise buildings on which the design-demandequations are based

\subsubsection{Phase 1: methodology to compare cold and hot water demand patterns of non-residential buildings}

The simulated patterns of the standardised buildings are compared with the measured daily patterns of cold and hot water. The comparison of the median demand patterns, allows to test the assumptions in the standardised buildings, concerning the presence of the users and their probability of water use during the day (see Table 4). Moreover, the height of the demand patterns gives information on the assumptions of average water use per person, defined in for example the frequency and use of water saving options of the toilets (see Table 5).

For each building, the medians of the measured diurnal patterns of cold and hot water demand are compared with the corresponding medians of simulated patterns of the standardised building. For an objective evaluation, the coefficient of determination $R^{2}$ is applied as statistical parameter. $R^{2}$ is a measure for the similarity between the patterns and calculated as:

$R^{2}=1-\sum_{i=1}^{N}\left(y_{i}-x_{i}\right)^{2} / \sum_{i=1}^{N}\left(x_{i}-\bar{x}\right)^{2}$

where $x_{i}$ is the measured data, $y_{i}$ is the simulated data and $\bar{x}$ is the mean of $x_{i}$. Good agreement between measurements and simulations is achieved when $R^{2}>0.70$ (Blokker et al., 2011).

\subsubsection{Phase 2: methodology to survey the construction of standardised buildings}

In each category of non-residential buildings, extensive surveys were held in at least four buildings of different typology. In the surveys the number and characteristics of users and appliances were investigated and compared with the construction of the standardised buildings, as is given for offices in 
Table 7. Number of interviewed buildings in each category of non-residential buildings and the requested information in the surveys.

\begin{tabular}{|c|c|c|c|c|c|}
\hline category & typology & $\begin{array}{l}\text { Number of } \\
\text { buildings }\end{array}$ & users & appliances & additional \\
\hline office & & 8 & $\begin{array}{l}\text { Number } \\
\text { Time of presence }\end{array}$ & $\begin{array}{l}\text { Number } \\
\text { Flow } \\
\text { Type }\end{array}$ & $\begin{array}{l}\text { Behaviour employees ( } 2 \text { offices): } \\
\text { Time and frequency of use (toilets, } \\
\text { urinals, coffee machine) } \\
\text { Type of use (saving options) } \\
\text { Use of appliances in kitchen ( } 1 \text { office): } \\
\text { duration and frequency }\end{array}$ \\
\hline \multirow[t]{2}{*}{ hotel } & business & $5^{*}$ & $\begin{array}{l}\text { Number } \\
\text { Time of presence }\end{array}$ & $\begin{array}{l}\text { Number } \\
\text { Flow } \\
\text { Type }\end{array}$ & $\begin{array}{l}\text { Behaviour business hotel guest: } \\
\text { frequency and duration of shower } \\
\text { and bath use }\end{array}$ \\
\hline & tourist & & & & $\begin{array}{l}\text { Behaviour tourist hotel guest: } \\
\text { frequency and duration of shower } \\
\text { and bath use }\end{array}$ \\
\hline \multirow[t]{2}{*}{$\begin{array}{l}\text { nursing } \\
\text { home }\end{array}$} & care needed residents & 5 & $\begin{array}{l}\text { Number } \\
\text { Time of presence }\end{array}$ & $\begin{array}{l}\text { Number } \\
\text { Flow } \\
\text { Type }\end{array}$ & $\begin{array}{l}\text { Intensity of use bedpan washer } \\
\text { Frequency of use toilet and shower } \\
\text { of residents }\end{array}$ \\
\hline & self-contained apartments & 3 & & & \\
\hline
\end{tabular}

${ }^{*}$ Hotels were not fully business or tourist. Some hotels were characterised as business on week days and tourist in weekend or $70 \%$ business and $30 \%$ tourist hotel. In the construction of standardised buildings, this does not cause problems, since the difference in water use is mainly caused by the different behaviour of a tourist guest and business guest.

Tables 4 and 5. In Table 7, the number of investigated buildings, the requested information of users and appliances in each functional room (see Table 2) and the additional information in different categories is summarised.

It was very difficult to collect these data. In practice, no survey send out to selected building owners were returned. It was required to collect the requested information by interviews. This was a highly labor and time intensive process: finding cooperation was a lengthy process, the information could not always be given by one person, the information was of a too high level of detail.

Agreement between the outcome of the surveys and the construction of the standardised buildings, was established in graphs in a visual way, a statistical test was not possible due to the limited number of buildings.

\subsection{Methodology validation step 2: validation of design- demand-equations for non-residential buildings based on SIMDEUM}

For the validation of the design-demand-equations, MMF and HWU from the design-demand-equations are compared with measured peak demand values with the following methodology:

a. MMF and HWU are taken from SIMDEUM based design-demand-equations for the selected buildings (Table 6).

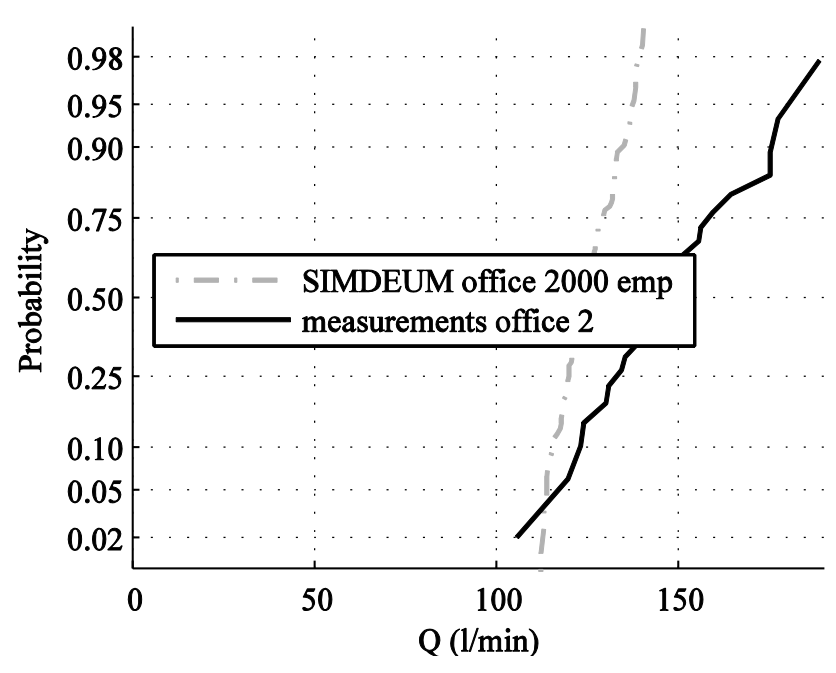

Figure 1. Frequency distribution of measured (24 weekdays at $1 \mathrm{~s}$ scale) and simulated (100 days at $1 \mathrm{~s}$ scale) peak demand values for office II: $Q=\mathrm{MMF}_{\text {cold }}\left[\mathrm{L} \mathrm{min}^{-1}\right]$.

b. measured MMF and HWU were determined as $\bar{x}+3 \cdot \sigma$, where $\bar{x}$ is the average value of the peak demand values from approx. 20-30 measured diurnal patterns and $\sigma$ is the corresponding standard deviation. For offices and nursing homes, the frequency distributions of the measured peak demand values follow a standard normal distribution as is illustrated in Fig. 1 for office II and in Fig. 2 for nursing home I. Therefore, the resulting 

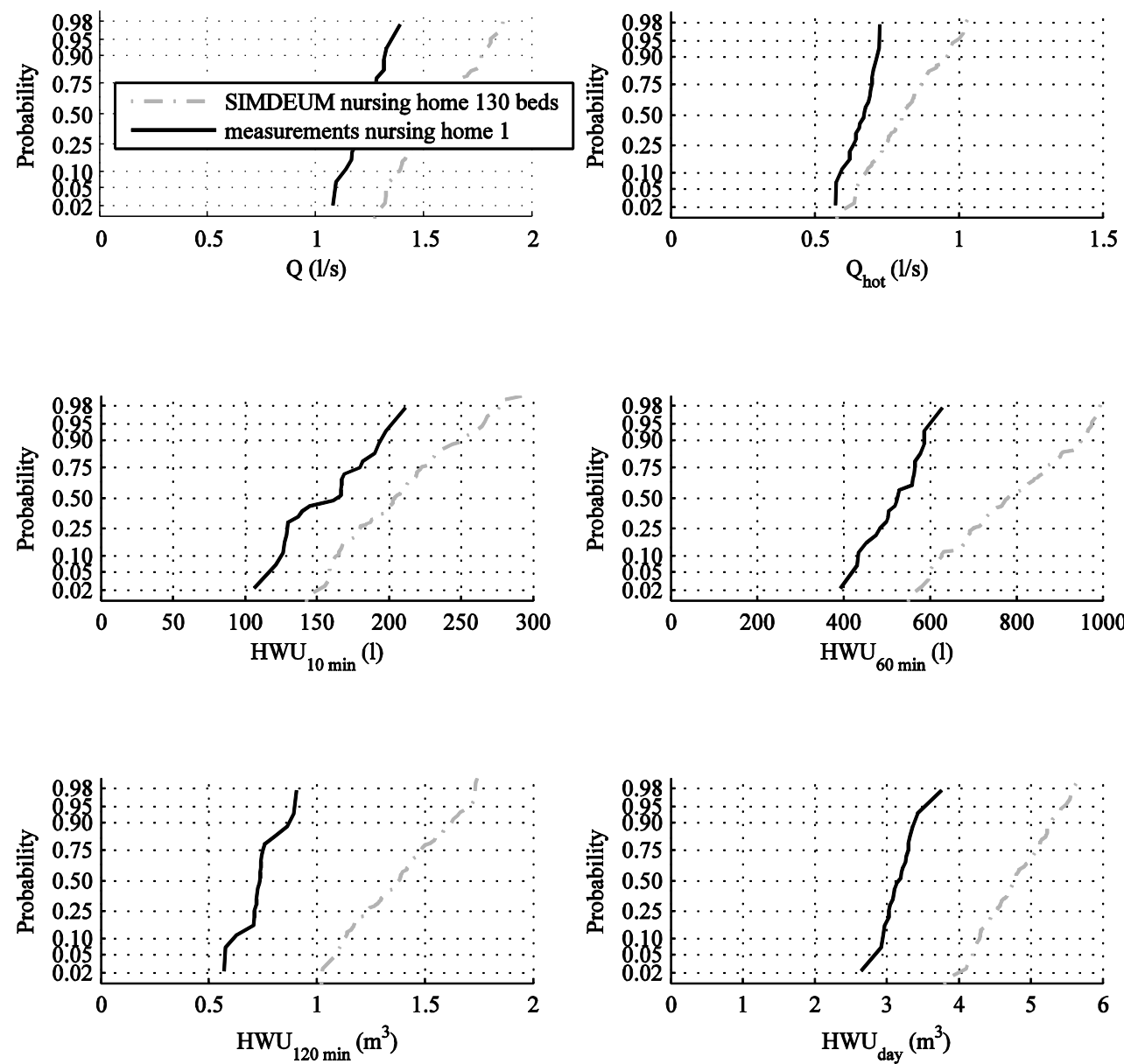

Figure 2. Frequency distribution of measured (26 weekdays at $1 \mathrm{~s} \mathrm{scale})$ and simulated (100 days at $1 \mathrm{~s}$ scale) peak demand values for nursing home I: (a) $\mathrm{MMF}_{\text {cold }}\left[\mathrm{L} \mathrm{s}^{-1}\right]$, (b) $\mathrm{MMF}_{\text {hot }}\left[\mathrm{L} \mathrm{s}^{-1}\right]$, (c) $\mathrm{HWU}_{10}[\mathrm{~L}]$, (d) $\mathrm{HWU}_{60}[\mathrm{~L}]$, (e) $\mathrm{HWU}_{120}\left[\mathrm{~m}^{3}\right]$, (f) $\mathrm{HWU}_{\text {day }}\left[\mathrm{m}^{3}\right]$.

MMF and HWU represent the 99.7-percentile. For hotels, the measured peak demand values do not follow a normal distribution due to the highly variable occupation (Fig. 3). The figure shows that the highest values of the peak demand fall in the last $10 \%$ of the measured peak demand values. In this region of the frequency distribution plot fall the water demand values of days with full occupation. The maximum value of the parameters (MMF and HWU) do not always coincide with the days with full occupation nor do they occur on the same day, e.g. $\mathrm{MMF}_{\text {cold }}$ and $\mathrm{HWU}_{10}$ take place at different days and even on days with low occupation. Therefore, the outcomes of the design-demand-equations are compared with the maximum value of each peak demand characteristic and with the average of the measured peak demand on the days with full occupation.

\subsection{Methodology to investigate the consequences for design of distribution systems and heating system}

The consequences of the new SIMDEUM based designdemand-equations are investigated by comparing the designs of the distribution systems and the heating system with designs in practice:

1. compare design distribution system based on MMF with designs in practice

The design of distribution systems is based on MMF, obtained with a time step of $1 \mathrm{~s}$. The maximum velocity $\left(v_{\max }\right)$ of flowing water in pipes, determines the selected diameter. The internal diameter of pipes is related to MMF (in $\left[\mathrm{L} \mathrm{s}^{-1}\right]$ ) and $v_{\max }$ by:

$d_{\text {in }}=\sqrt{\frac{\mathrm{MMF} / 1000}{0.25 \cdot \pi \cdot v_{\max }}} \cdot 1000[\mathrm{~mm}]$

where $v_{\max }$ is the maximal allowed design velocity set at $2 \mathrm{~m} \mathrm{~s}^{-1}, d_{\text {in }}$ is the internal pipe diameter in $\mathrm{mm}$. The calculated internal diameter is compared with a limited 

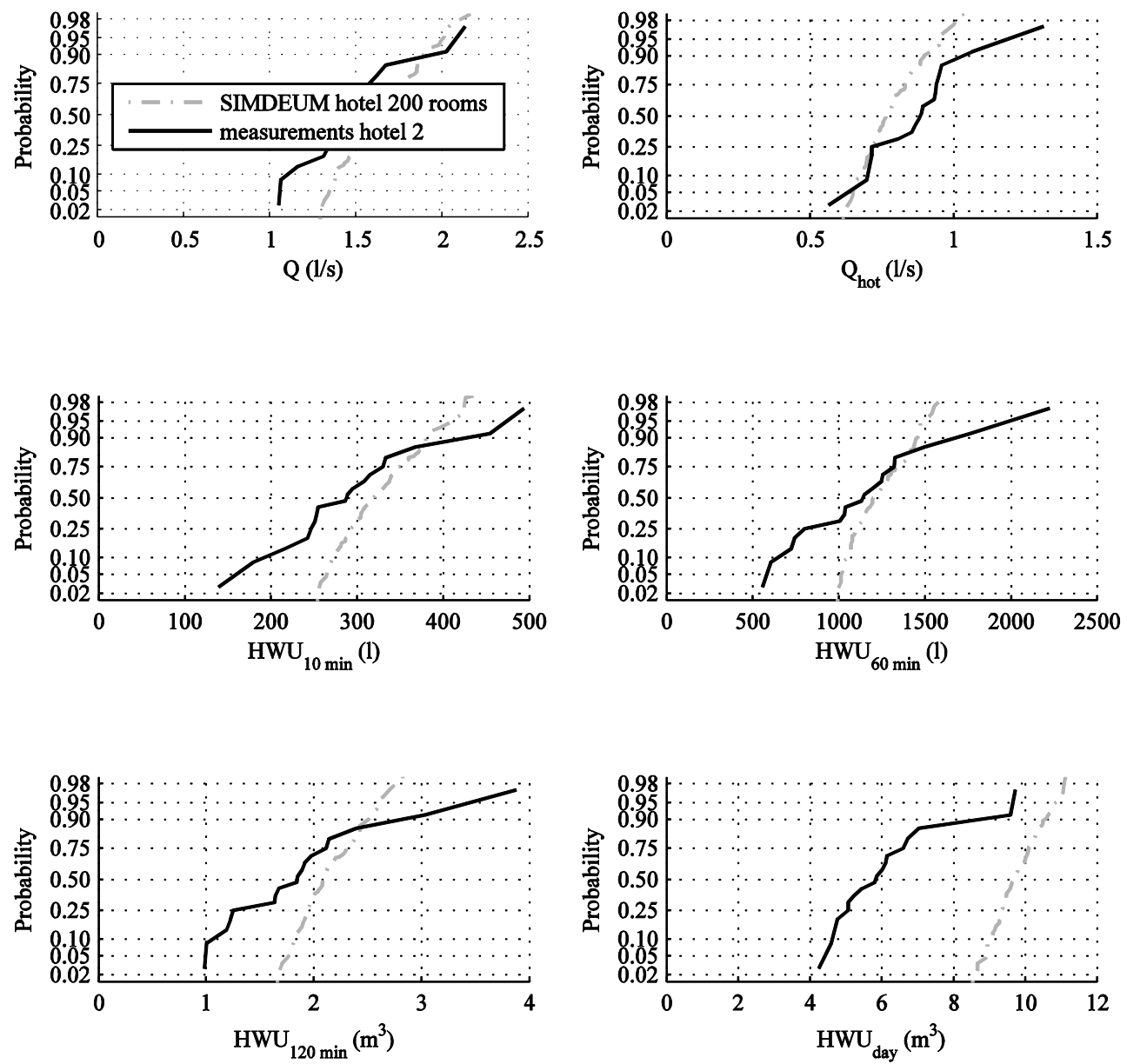

Figure 3. Frequency distribution of measured (18 weekdays at $1 \mathrm{~s}$ scale) and simulated (100 days at $1 \mathrm{~s} \mathrm{scale)}$ ) peak demand values for hotel II: (a) $\mathrm{MMF}_{\text {cold }}\left[\mathrm{L} \mathrm{s}^{-1}\right]$, (b) $\mathrm{MMF}_{\text {hot }}\left[\mathrm{L} \mathrm{s}^{-1}\right]$, (c) $\mathrm{HWU}_{10}[\mathrm{~L}]$, (d) $\mathrm{HWU}_{60}[\mathrm{~L}]$, (e) $\mathrm{HWU}_{120}\left[\mathrm{~m}^{3}\right]$, (f) $\mathrm{HWU}_{\text {day }}\left[\mathrm{m}^{3}\right]$.

number of practical copper pipe diameters, applied in drinking water systems. The smallest copper pipe fulfilling the calculated internal diameter is selected in design.

2. compare design heating system based on $M M F_{\text {hot }}$ and $H W U$ with designs in practice

The outcome of the SIMDEUM based design-demandequations for the characteristics of hot water demand, $\mathrm{MMF}_{\text {hot }}, \mathrm{HWU}_{10}, \mathrm{HWU}_{60}, \mathrm{HWU}_{120}$ and $\mathrm{HWU}_{\text {day }}$ are applied in general design tools to determine the desired volume ( $V$ in $[\mathrm{L}])$ and power $(P$ in $[\mathrm{kW}])$ of a hot water charging system (ISSO-55, 2001). The resulting dimensions of the heating systems based on SIMDEUM are compared with dimensions proposed by different suppliers of heating systems for various buildings.

\section{Results and discussion}

4.1 Validation step 1: validation of how to standardise buildings on which the design-demand-equations are based

\subsubsection{Phase 1: validation of cold and hot demand patterns of standardised non-residential buildings}

The simulated patterns of the standardised buildings are compared with the measured daily patterns of cold and hot water. In Fig. 4 an example is given for one building in each category. The visually good agreement between the daily patterns is confirmed by the values of $R^{2}$ which is larger than 0.70 for offices, for cold water in nursing home I and for both cold and hot water in the nursing home II (Table 8). The lower value for hot water in nursing home I, is caused by the cleaning of the wash bowls on one location and at one specific moment in the afternoon, which was not applied in standardised nursing home. The lower value for hotels is most probably due to the 
Table 8. Statistics of the comparison between measured and simulated water demands for offices, business hotels and nursing homes and their corresponding standardised buildings.

\begin{tabular}{llllllll}
\hline category offices & $R^{2}$ & category hotels & \multicolumn{2}{c}{$R^{2}$} & category nursing homes & \multicolumn{2}{c}{$R^{2}$} \\
& cold & & cold & hot & & cold & hot \\
\hline \multirow{2}{*}{ office I } & 0.90 & business hotel I & 0.54 & 0.49 & nursing home I & 0.71 & 0.38 \\
\hline \multirow{2}{*}{ office II } & 0.96 & business hotel II & 0.45 & 0.50 & nursing home II & 0.82 & 0.71 \\
& & & 0.61 & 0.59 & & & \\
\hline
\end{tabular}

varying occupation of the hotel. The morning peak appears later in reality and there is a difference in evening peak.

This phase shows that the assumptions made for the presence of users, their probability of water use during the day and for average water use per user are reliable for offices and nursing homes. For hotels, the presence of hotel guests and their probability of water use during the day is not estimated very well, following from the differences in morning and evening peak demand. On the other hand, the average water use per user is estimated in a reliable way, following from the height of the demand patterns.

This phase also shows the advantage of using the physically based SIMDEUM for the development of designdemand-equations, since differences can be interpreted and explained.

\subsubsection{Phase 2: validation of construction of standardised non-residential buildings}

The construction of the standardised buildings is validated by comparing the number and characteristics of appliances and users in all functional rooms (Table 2). The surveys mainly give information on the ratio between users and appliances. As an illustration, the results for offices are presented in Fig. 5, where the outcome of the surveys for number of users are shown together with the relations of the standardised building (Table 4). Figure 5a shows that the number of users in the dominant functional room, i.e. the meeting area (Table 3) corresponds well with practice. Also the behaviour of the users, like the frequency of toilet use, the use of coffee machine and the time of presence correspond well. In practice, the water saving options of the toilet flush are used less frequently than assumed in the standardised building. On the other hand, the number of users in the other functional rooms, such as the restaurant, the fitness room and the technical room (Fig. 5b) show higher variations and are less accurate. Moreover, the data from the surveys show that it is not possible to extract a more appropriate standard from the available data. The same is true for the appliances: the number and types of appliances in the dominant functional room, like the number of toilets for men and women, the number of wash basins and the number of coffee machines correspond well with practice. Only the number of urinals is lower in practice than assumed in the standardised office. This means that in the standardised offices a higher simultaneous use of urinals is possible, which might result in a higher peak demand predicted by the design-demand-equations. The assumptions for the number of appliances in other functional rooms are reasonable. Sometimes, not enough information can be extracted from the surveys to draw any conclusions.

The surveys indicate that the equipment of the standardised office is reliable for the dominant functional room, the meeting area. The functional room, that contributes most to the pattern and total amount of water use in a building is equipped corresponding with practice: the number of users and their water using behaviour as well as the number of appliances correspond with the surveyed offices. The agreement between the simulated and measured demand patterns of $R^{2}>0.90$ (Fig. 4a) means that a reliable equipment of the functional room in the standardised office is sufficient for a realistic prediction of the water demand of a building. Moreover, it shows that as long as the ratio between users and appliances is not extreme, for example when there are not enough toilets for the users causing queues, the exact ratio is not crucial. This gives SIMDEUM the possibility to be less exact, while still predicting the water demand in a reliable way.

The same tendency is found for hotels and nursing homes. The dominant functional rooms in the standardised buildings, respectively the hotel rooms for hotels and the lodging and meeting area for nursing homes have a reliable equipment regarding the number of users and appliances. The other functional rooms are less accurate and it is not possible to find better relations to equip the other functional rooms in the standardised buildings with users and appliances from the surveys. The reliable equipment of the dominant functional rooms is sufficient for a reliable prediction of the expected cold and hot water demand in the building (Fig. 4b and c). In short, the proof of concept is established for all considered categories of non-residential buildings (Pieterse-Quirijns et al., 2013a, b, c).

\subsection{Validation step 2: validation of design-demand- equations for peak demand values for cold and hot water}

The measured peak demand values for all non-residential buildings are presented in Table 9. This table also includes 

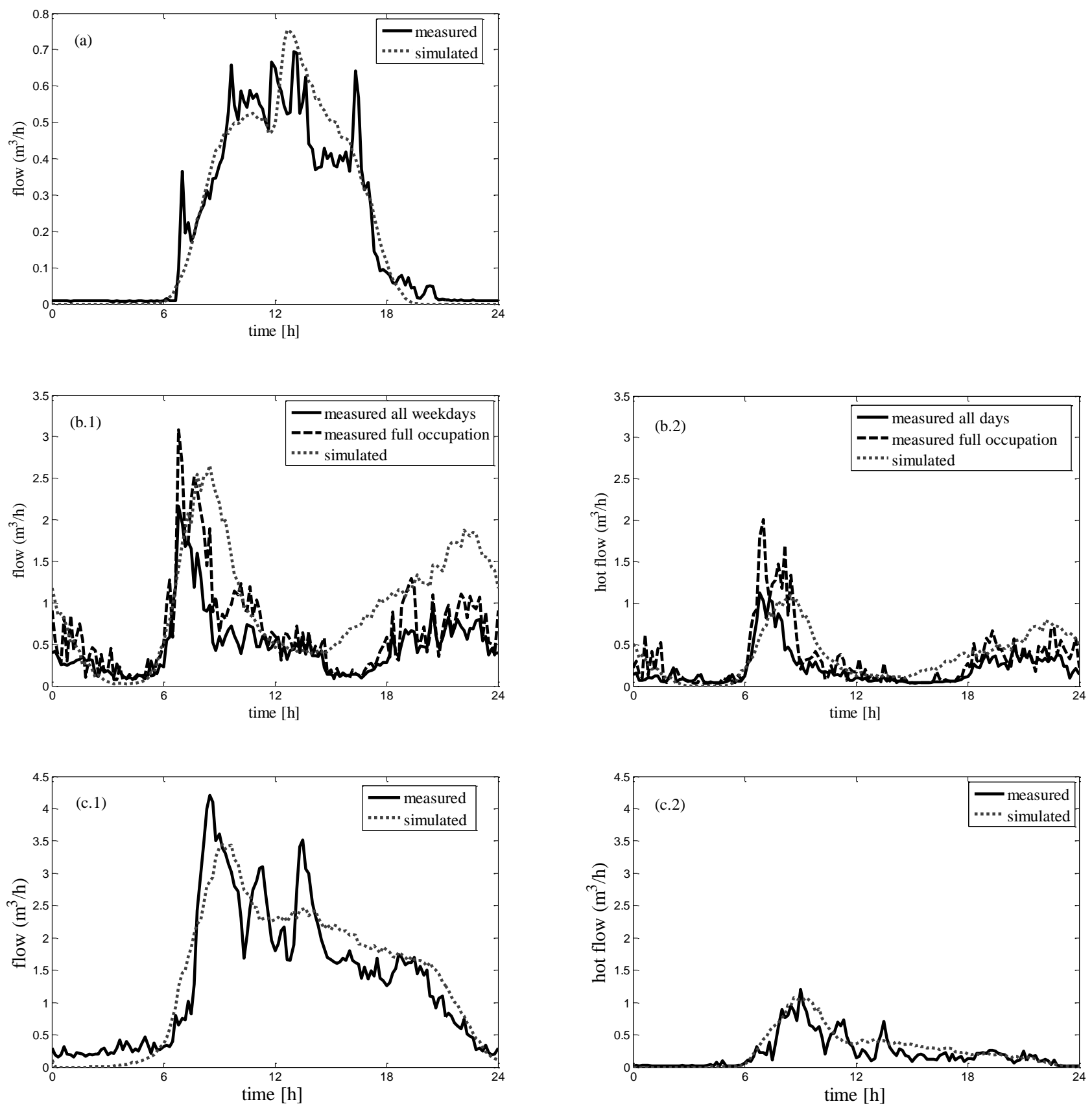

Figure 4. Comparing average measured and simulated demand of cold water of office I (a), cold water (b.1.) and hot water (b.2.) of a business hotel (II) during weekdays and cold water (c.1.) and hot water (c.2.) of a nursing home (II) with care needed residents during weekdays.

the predicted peak demand values by the newly developed design-demand-equations, based on SIMDEUM. For offices of different sizes, the SIMDEUM based design-demandequations predict the $\mathrm{MMF}_{\text {cold }}$ well. They slightly underestimate the $\mathrm{MMF}_{\text {cold }}$ with $10 \%$.

For hotels, the derivation of peak demand values from the measured water demand patterns is difficult, due to the varying occupation. 30 measuring days appears to be too short to achieve a statistically sound procedure because of the additional variation due to variable occupation (Fig. 3). For statistically sound conclusions for hotels with varying occupations a longer measuring period is recommended. Careful comparison shows that the deviation between measured peak demand and the outcome of the design-demandequations varies from an underestimation of maximal $30 \%$ to an overestimation of maximal $15 \%$. The $\mathrm{MMF}_{\text {cold }}$ can be predicted fairly well, while the hot water demand appears to be (slightly) underestimated. 

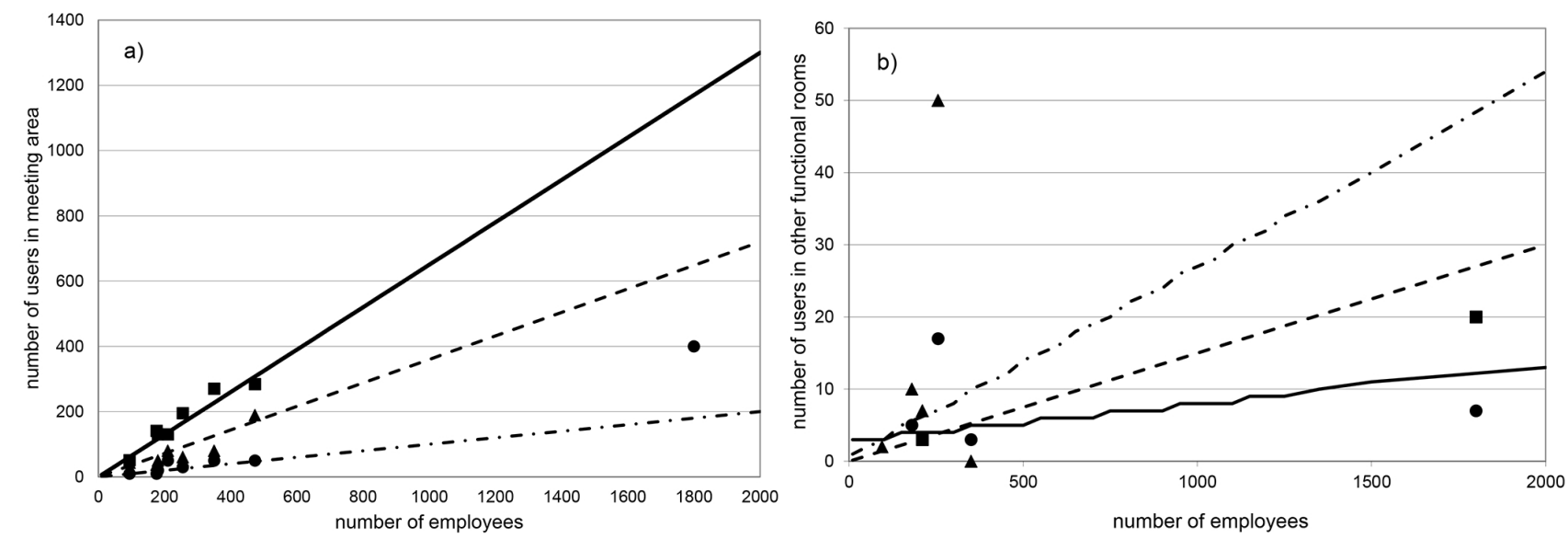

Figure 5. Number of users in the standardised office of design-demand-equations (lines) and in surveyed offices (data points) in the dominant functional room of offices, meeting area (a) with male employees (- and $\boldsymbol{a})$, female employees (- - and $\mathbf{\Delta})$ and visitors (-.- and $\bullet$ ) and in other functional rooms (b) with kitchen personnel (- and $\mathbf{\square})$, employees using the fitness room (- - and $\mathbf{\Delta})$ and cleaners (-.- and $\bullet$ ).

The new design-demand-equations predict a higher cold and hot water demand of the nursing homes (2-72\%), except for $\mathrm{MMF}_{\text {hot }}$ in nursing home II, that is underestimated with $16 \%$. The higher predicted water demand can be caused by the assumed higher number of personnel in the standardised nursing homes (following from phase 2 in validation step 1). Moreover, in nursing home I the different practice in cleaning the wash bowls plays a role.

This paper shows that the solid basis of SIMDEUM and the standardisation of buildings for offices, hotels and nursing homes result in a reliable prediction of peak demand values by the design-demand-equations derived with the procedure based on SIMDEUM. With this paper it is shown that the procedure leads to good results for three types of nonresidential buildings. The way we demonstrate this, is by not only showing that the procedure leads to good end results (maximum flows and hot water uses), but also by showing that the underlying principle (the assumptions of the appliances and people in the buildings and the resulting diurnal patterns of cold and hot water) is sound. These results suggest that the procedure for the design-demand-equations will result in reliable prediction for other small-scale buildings, when the standardisation of the buildings is solid. Due to the modular approach of SIMDEUM and its physical basis, it is possible to construct a specific building and simulate its water demand following a few steps: define the functional rooms where water is used, and equip each functional room with its typical users and appliances. From each user, the time of presence, the time and frequency of use needs to be estimated, which can be done with logical thinking, experience or interviews. This paper illustrates that mainly the dominant user or functional room needs to be equipped well. For many small-scale buildings these can be determined quite easy: for example toilet rooms in schools, used by children and used by teachers, toilet in a shop, etc. In this way,
SIMDEUM was used to develop diurnal profiles for several different buildings, like schools, shops, restaurants, sporting facilities etc. (Pieterse-Quirijns and Van de Roer, 2013). One example is described in Blokker et al. (2011), where a theatre hotel is shown.

\subsection{Consequences for design of distribution systems and heating system}

The design of the outside and inside distribution system is based on the maximum momentary flows $\left(\mathrm{MMF}_{\text {cold }}\right.$ and $\mathrm{MMF}_{\text {hot }}$ ) for pipes distributing the total amount of water and the hot water pipes respectively. In Table 9, the resulting pipe diameters are shown, based on the measured and the predicted peak demand values. The table shows that the newly developed design-demand-equations result in the same design as the measurements would. This indicates that the deviation between the design-demand-equations and the measurements falls within the design accuracy, given by the limited number of existing pipe diameters.

In the same table, the diameters resulting from water demands predicted with old guidelines (Table 1) and applied in practice are included. The old guidelines always result in a larger diameter than the new design-demand-equations, caused by a large overestimation of the expected water demand. The old guidelines overestimate the $\mathrm{MMF}_{\text {cold }}$ with $30-80 \%$ for offices, with $70-170 \%$ for hotels, and with $75-$ $166 \%$ for nursing homes, which is much larger than the deviations of the new design-demand-equations.

Moreover, the design-demand-equations also result in smaller diameters than applied in practice, while still meeting the desired comfort wish (resulting from the measurements). The table shows that the practical diameters are even larger than the diameters resulting from the old guidelines. Apparently, extra safety factors are applied in practice. 
Table 9. Comparison of the measured peak demand values for cold and hot water with the outcome of the SIMDEUM based design-demandequations ("new") and existing guidelines for cold water ("old") for non-residential buildings (offices, hotels and nursing homes) and the resulting pipe diameters compared with diameters used in practice $\left(d_{\text {pract. }}\right)$. Deviation from measured peak demand values is shown between brackets.

\begin{tabular}{|c|c|c|c|c|c|c|c|c|c|c|}
\hline \multirow[t]{2}{*}{ Building } & \multirow[t]{2}{*}{$\begin{array}{l}\text { Peak demand } \\
\text { parameter }\end{array}$} & \multicolumn{5}{|c|}{ Peak demand value } & \multicolumn{4}{|c|}{$\begin{array}{l}\text { Consequences for of pipes [mm] } \\
\text { selection diameter }\end{array}$} \\
\hline & & \multirow[t]{2}{*}{ measured } & \multicolumn{2}{|c|}{ design-demand-equations } & \multicolumn{2}{|c|}{ old guidelines } & \multirow[t]{2}{*}{$d_{\text {pract. }}$} & \multirow[t]{2}{*}{$d_{\text {meas. }}$} & \multirow{2}{*}{$d_{\text {new }}$} & \multirow[t]{2}{*}{$d_{\text {old }}$} \\
\hline \multicolumn{6}{|c|}{ offices } & & & & & \\
\hline office I & $\mathrm{MMF}_{\text {cold }}\left[\mathrm{Ls}^{-1}\right]$ & 1.1 & 1.0 & $(-11 \%)$ & 1.9 & $(+79 \%)$ & 54 & 35 & 35 & 42 \\
\hline office II & $\mathrm{MMF}_{\text {cold }}\left[\mathrm{Ls} \mathrm{s}^{-1}\right]$ & 4.0 & 3.7 & $(-8 \%)$ & 5.3 & $(+32 \%)$ & 54 & 54 & 54 & 64 \\
\hline \multicolumn{11}{|c|}{ hotels } \\
\hline \multicolumn{11}{|c|}{ based on maximal measured values (not on the same day) } \\
\hline \multirow[t]{6}{*}{ business hotel I } & $\mathrm{MMF}_{\text {cold }}\left[\mathrm{L} \mathrm{s}^{-1}\right]$ & 1.9 & 1.3 & $(-27 \%)$ & 3.1 & $(+69 \%)$ & 76 & 42 & 35 & 54 \\
\hline & $\mathrm{MMF}_{\text {hot }}\left[\mathrm{Ls}^{-1}\right]$ & 0.8 & 0.8 & $(-10 \%)$ & - & & 54 & 28 & 28 & - \\
\hline & $\mathrm{HWU}_{10}[\mathrm{~L}]$ & 339 & 293 & $(-14 \%)$ & - & & & & & \\
\hline & $\mathrm{HWU}_{60}[\mathrm{~L}]$ & 987 & 851 & $(-14 \%)$ & - & & & & & \\
\hline & $\mathrm{HWU}_{120}[\mathrm{~L}]$ & 1500 & 1360 & $(-9 \%)$ & - & & & & & \\
\hline & $\mathrm{HWU}_{\text {day }}[\mathrm{L}]$ & 5560 & 4998 & $(-10 \%)$ & - & & & & & \\
\hline \multicolumn{11}{|c|}{ based on average measured values during full occupation } \\
\hline \multirow[t]{6}{*}{ business hotel I } & $\mathrm{MMF}_{\text {cold }}\left[\mathrm{Ls}^{-1}\right]$ & 1.5 & 1.3 & $(-11 \%)$ & 3.1 & $(+107 \%)$ & 76 & 35 & 35 & 54 \\
\hline & $\mathrm{MMF}_{\text {hot }}\left[\mathrm{L} \mathrm{s}^{-1}\right]$ & 0.7 & 0.8 & $(+11 \%)$ & - & & 54 & 28 & 28 & - \\
\hline & $\mathrm{HWU}_{10}[\mathrm{~L}]$ & 255 & 293 & $(+15 \%)$ & - & & & & & \\
\hline & $\mathrm{HWU}_{60}[\mathrm{~L}]$ & 844 & 851 & $(+1 \%)$ & - & & & & & \\
\hline & $\mathrm{HWU}_{120}[\mathrm{~L}]$ & 1288 & 1360 & $(+6 \%)$ & - & & & & & \\
\hline & $\mathrm{HWU}_{\text {day }}[\mathrm{L}]$ & 5143 & 4998 & $(-3 \%)$ & - & & & & & \\
\hline \multicolumn{11}{|c|}{ based on maximal measured values (not on the same day) } \\
\hline \multirow[t]{6}{*}{ business hotel II } & $\mathrm{MMF}_{\text {cold }}\left[\mathrm{Ls}^{-1}\right]$ & 2.0 & 2.1 & $(+2 \%)$ & 4.8 & $(+139 \%)$ & 67 & 42 & 42 & 64 \\
\hline & $\mathrm{MMF}_{\mathrm{hot}}\left[\mathrm{Ls} \mathrm{s}^{-1}\right]$ & 1.3 & 1.1 & $(-18 \%)$ & - & & 54 & 35 & 35 & - \\
\hline & $\mathrm{HWU}_{10}[\mathrm{~L}]$ & 494 & 455 & $(-8 \%)$ & - & & & & & \\
\hline & $\mathrm{HWU}_{60}[\mathrm{~L}]$ & 2225 & 1594 & $(-28 \%)$ & - & & & & & \\
\hline & $\mathrm{HWU}_{120}[\mathrm{~L}]$ & 3882 & 2667 & $(-31 \%)$ & - & & & & & \\
\hline & $\mathrm{HWU}_{\text {day }}[\mathrm{L}]$ & 9732 & 10574 & $(+9 \%)$ & - & & & & & \\
\hline \multicolumn{11}{|c|}{ based on average measured values during full occupation } \\
\hline business hotel II & $\mathrm{MMF}_{\text {cold }}\left[\mathrm{L} \mathrm{s}^{-1}\right]$ & 1.8 & 2.1 & $(+15 \%)$ & 4.8 & $(+170 \%)$ & 67 & 42 & 42 & 64 \\
\hline & $\mathrm{MMF}_{\mathrm{hot}}\left[\mathrm{L} \mathrm{s}^{-1}\right]$ & 1.2 & 1.1 & $(-10 \%)$ & - & & 54 & 35 & 35 & - \\
\hline & $\mathrm{HWU}_{10}[\mathrm{~L}]$ & 474 & 455 & $(-4 \%)$ & - & & & & & \\
\hline & $\mathrm{HWU}_{60}[\mathrm{~L}]$ & 1994 & 1594 & $(-20 \%)$ & - & & & & & \\
\hline & $\mathrm{HWU}_{120}[\mathrm{~L}]$ & 3457 & 2667 & $(-23 \%)$ & - & & & & & \\
\hline & $\mathrm{HWU}_{\text {day }}[\mathrm{L}]$ & 9662 & 10574 & $(+9 \%)$ & - & & & & & \\
\hline & & & & arsing homes & & & & & & \\
\hline nursing home I & $\mathrm{MMF}_{\text {cold }}\left[\mathrm{Ls}^{-1}\right]$ & 1.5 & 1.9 & $(+31 \%)$ & 3.9 & $(+166 \%)$ & 42 & 35 & 42 & 54 \\
\hline & $\mathrm{MMF}_{\mathrm{hot}}\left[\mathrm{L} \mathrm{s}^{-1}\right]$ & 0.8 & 1.0 & $(+27 \%)$ & - & & $2 \times 28$ & 28 & 28 & - \\
\hline & $\mathrm{HWU}_{10}[\mathrm{~L}]$ & 243 & 294 & $(+21 \%)$ & - & & & & & \\
\hline & $\mathrm{HWU}_{60}[\mathrm{~L}]$ & 698 & 1041 & $(+49 \%)$ & - & & & & & \\
\hline & $\mathrm{HWU}_{120}[\mathrm{~L}]$ & 983 & 1693 & $(+72 \%)$ & - & & & & & \\
\hline & $\mathrm{HWU}_{\text {day }}[\mathrm{L}]$ & 3830 & 5366 & $(+40 \%)$ & - & & & & & \\
\hline nursing home II & $\mathrm{MMF}_{\text {cold }}\left[\mathrm{L} \mathrm{s}^{-1}\right]$ & 3.2 & 3.3 & $(+2 \%)$ & 5.6 & $(+75 \%)$ & $54+35$ & 54 & 54 & 76 \\
\hline (260 beds cold) & $\mathrm{MMF}_{\mathrm{hot}}\left[\mathrm{Ls}^{-1}\right]$ & 1.9 & 1.6 & $(-16 \%)$ & - & & 54 & 42 & 42 & - \\
\hline ( 212 beds hot) & $\mathrm{HWU}_{10}[\mathrm{~L}]$ & 381 & 454 & $(+19 \%)$ & - & & & & & \\
\hline & $\mathrm{HWU}_{60}[\mathrm{~L}]$ & 1432 & 1853 & $(+29 \%)$ & - & & & & & \\
\hline & $\mathrm{HWU}_{120}[\mathrm{~L}]$ & 2354 & 3122 & $(+33 \%)$ & - & & & & & \\
\hline & $\mathrm{HWU}_{\text {day }}[\mathrm{L}]$ & 7198 & 11861 & $(+65 \%)$ & - & & & & & \\
\hline
\end{tabular}


Table 10. Dimensions of heating systems for different type of buildings, based on measured hot water demand, based on SIMDEUM based design-demand-equations and proposed by companies.

\begin{tabular}{lrrrrrr}
\hline type of building & \multicolumn{2}{c}{$\begin{array}{c}\text { design based on } \\
\text { measurements }\end{array}$} & $\begin{array}{r}\text { design based on } \\
\text { SIMDEUM }\end{array}$ & \multicolumn{2}{c}{$\begin{array}{c}\text { proposal } \\
\text { company }\end{array}$} \\
\cline { 2 - 7 } & $V[\mathrm{~L}]$ & $P[\mathrm{~kW}]$ & $V[\mathrm{~L}]$ & $P[\mathrm{~kW}]$ & $V[\mathrm{~L}]$ & $P[\mathrm{~kW}]$ \\
\hline hotel I (small business) & 500 & 30 & 500 & 35 & 1000 & 200 \\
hotel II (large business) & 1000 & 85 & 1000 & 60 & 4000 & 200 \\
hotel III (tourist) & & & 250 & 50 & 740 & 100 \\
nursing home I & 500 & 25 & 500 & 45 & & \\
nursing home II & 1000 & 55 & 1000 & 75 & & 45 \\
nursing home III: care needed residents & & & 250 & 25 & 500 & \\
nursing home IV: self-contained apartments & & & 500 & 37.5 & 1000 & 100 \\
with independent resident & & & & & & \\
\hline
\end{tabular}

With the supply of the same amount of water, the smaller diameters will result in better water quality with respect to hygiene, due to higher velocities and less stagnancy. Moreover, reducing pipe diameters, also reduces the actual surface areas of pipework material to support biofilm growth, whilst also reducing the sizes of bracketing, ancillaries and insulation material. This contributes to a more sustainable use of materials and reduced installation costs (Angus et al., 2010).

The resulting dimensions of the water heating systems based on SIMDEUM are compared with dimensions proposed by different suppliers of heating systems, presented in Table 10. To know which dimensions are required to meet the comfort in a building, the measured hot water demands, when available, are also applied in the same design tool for a heating system. The dimensions based on measured hot water demands are also given in Table 10. For a small business hotel, the actual measured hot water demand, during full occupation requires a heating system with a volume of $500 \mathrm{~L}$ and a power of $30 \mathrm{~kW}$. The dimensions resulting from the by SIMDEUM predicted hot water demand are $500 \mathrm{~L}$ and $35 \mathrm{~kW}$. The supplier, on the other hand, proposes for this hotel a heating system of $1000 \mathrm{~L}$ and $200 \mathrm{~kW}$. This comparison shows that SIMDEUM does not underestimate the dimensions of the heating system, while the supplier's overestimation is large. This tendency is generally found for different types of buildings (Table 10). The suppliers of heating systems propose heaters with too large capacities, both in volume and power that do not match with the actual hot water demand. The proposed capacities are 2 and sometimes 4 times larger than needed. This shows that SIMDEUM based design-demand-equations result in heating systems that still fulfil the desired comfort wish, while being more energy efficient. The smaller heaters require less energy to heat the system and will have less energy losses. Moreover, the smaller design of the heating system reduces the stagnancy of water, which might lead to less hygienic problems.
The paper shows that SIMDEUM forms a reliable basis to predict non-residential cold and hot water demand. The new SIMDEUM based design-demand-equations lead to smaller diameters and reduced capacity of heating systems. These designs diverge from the common practice in the Netherlands. In this paper it is shown that the common practice leads to oversized systems. In other countries the same tendency is expected, although international guidelines do not exist in the public domain. Therefore, it is recommended to apply the SIMDEUM based procedure to develop designdemand-equations for peak demand values for various building types in specific countries to improve the designs. Due to the physical basis of SIMDEUM, the presented procedure is easily transferable to other countries when specific information on users and appliances is available. Also in other countries, we succesfully used SIMDEUM for simulating the water demand for residential water use.

The US National Bureau of Standards approach to determine the MMF (the so called Hunter's curves) has been incorporated into design codes for plumbing systems. Present day experience indicates that Hunter's curves often overestimate actual water demands. There is recognition of a need to update methods for estimating peak water demands in plumbing systems to better reflect today's high efficiency water fixtures and realistically account for non-congested conditions in a variety of end use applications (e.g. residential, commercial, institutional, etc.). Buchberger et al. (2012) suggest an update of Hunter's method, following an analytical approach. It would be worthwhile to compare these analytical estimates for the peak demand with the ones obtained from the measurements and from the SIMDEUM based design-demand-equations.

\section{Conclusions}

Recently, new SIMDEUM based design-demand-equations were developed for cold and hot water demand of nonresidential buildings. In this paper, these design-demand- 
equations are validated with measurements of both cold and hot water on a per second basis for different buildings and with surveys.

Firstly, the assumptions of building standardisation, on which the design-demand-equations are based, were validated with surveys and measurements of both cold and hot water on a per second basis for six different non-residential buildings, offices, hotels and nursing homes. The validation shows that the model predicts the cold and hot water daily demand patterns reasonably well to good. The correlation of the simulated patterns with the measured patterns indicates that the basis of the design-demand-equations is solid.

Moreover, the construction of standardised buildings with users and appliances is validated with at least four surveys per category of non-residential buildings. The validation proves that with a proper estimation of the number of users and appliances in only the dominant functional room of the standardised buildings, SIMDEUM renders a realistic cold and hot water diurnal demand pattern.

With the correspondence between standardised buildings and reality, in both diurnal water demand patterns and construction of the building, the solid base of SIMDEUM based design-demand-equations is proven by the proof of concept, i.e. when the construction is reliable, the prediction of the expected cold and hot water demand in the building will be reliable.

Secondly, the outcome of the design-demand-equations is validated. The validation shows that the design-demandequations predict the cold and hot water demand peak values reasonable to good. The deviation of the predicted demand values from the measured ones is mostly less than $15 \%$. Sometimes a higher deviation is found, but less than $30 \%$. Only the deviation of the predicted hot water demand of nursing homes is higher, caused by a higher assumed number of personnel or another cleaning practice. These deviations are much smaller than the deviations of existing guidelines for $\mathrm{MMF}_{\text {cold }}$ which overestimate by $30-170 \%$. Moreover, the new design-demand-equations give insight into hot water use, where no existing public guidelines are available.

The new design-demand-equations improve the design of the building installation, expressed as the selected pipe diameters, and of the heating system. First of all, the design-demand-equations lead to the same pipe diameter and the same heating system as based on the measured peak values. This means that the design based on the new rules is reliable. Secondly, the selected pipe diameters are smaller than the ones used in practice and the ones predicted by the existing guidelines. This indicates that the common practice leads to oversized systems, with corresponding potential quality problems. Also the heater capacity can be reduced based on the outcome of the design-demand-equations. SIMDEUM based design-demand-equations reduce the design of a heater capacity with a factor 2 to 4 compared to suppliers proposals, while still meeting the desired need and comfort. Thus, the improved insight of the new designdemand-equations will lead to an energy efficient choice of the hot water systems, and thus save energy. Moreover, the smaller design of the heating system reduces the possibility of stagnant water, that might reduce the chance on hygienic problems.

Edited by: R. Farmani

\section{References}

Angus, P., Ingle, S., King, D., and Turner, J.: The effects of using water velocity as a technique to control biofilm development in water supply systems, Water Supply and Drainage for Buildings, CIB W062, Sydney, Australia, 8-10 November, 106-124, 2010.

Baggelaar, P. K. and Geudens, P. J. J. G.: Prognose landelijke drinkwatervraag t/m 2005, Vewin, Rijswijk, The Netherlands, 2008.

Barberán, R., Egea, P., Gracia-de-Rentería, P., and Salvador, M.: Evaluation of water saving measures in hotels: a Spanish case study, Int. J. Hosp. Manag., 34, 181-191, 2013.

Blokker, E. J. M. and Van der Schee, W.: Simulation of water demands provides insight, Water Supply and Drainage for Buildings, CIB W062, Taipee, Taiwan, 18-20 September, 2006.

Blokker, E. J. M., Vreeburg, J. H. G., and Van Dijk, J. C.: Simulating residential water demand with a stochastic end-use model, J. Water Res. Pl.-ASCE, 136, 19-26, 2010.

Blokker, E. J. M., Pieterse-Quirijns, E. J., Vreeburg, J. H. G., and van Dijk, J. C.: Simulating non-residential water demand with a stochastic end-use model, J. Water Res. Pl.-ASCE, 137, 511520, 2011.

Buchberger, S. G., Blokker, E. J. M., and Cole, D.: Estimating peak water demands in hydraulic systems I - current practice, Water Distribution System Analysis, WDSA 2012, Adelaide, Australia, 24-27 September 2012.

Cobacho, R., Arregui, F., Parra, J. C., and Cabrera Jr., E.: Improving efficiency in water use and conservation in Spanish hotels, Water Sci. Technol., 5, 273-279, 2005.

Ilemobade, A. A., Van Zyl, J. E., and Van Zyl, H. J.: New guidelines for non-domestic water estimation in South Africa, in: Integrating Water Systems CCWI 2009, CRC Press/Balkema Leiden, Sheffield, UK, 543-549, 2010.

ISSO-55: ISSO - publicatie 55; Tapwaterinstallaties voor woon - en utiliteitsgebouwen, Stichting ISSO, Rotterdam, The Netherlands, 2001.

Loureiro, D., Coelho, S. T., Rebelo, M., Ramalho, P., Alegre, H., Covas, D. I. C., and Pina, A.: Correlating water consumption behaviour with billing, infrastructure and sociodemographic factors, in: Integrating Water Systems CCWI 2009, CRC Press/Balkema Leiden, Sheffield, UK, 105-111, 2010.

Pieterse-Quirijns, E. J. and Van de Roer, M.: Verbruikspatronenbibliotheek, KWR, Nieuwegein, The Netherlands, 2013.

Pieterse-Quirijns, E. J., Blokker, E. J. M., and Vogelaar, A. J.: Modelleren van niet-huishoudelijk waterverbruik; waterverbruik van kantoren, hotels, zorginstellingen en veehouderij, KWR, Nieuwegein, The Netherlands, 2009.

Pieterse-Quirijns, E. J., Blokker, E. J. M., Van der Blom, E., and Vreeburg, J. H. G.: Modelling characteristic values for non-residential water use, Water Distribution System Analysis, WDSA 2010, Tuscon, AZ, USA, 12-15 September, 2010. 
Pieterse-Quirijns, E. J., Beverloo, H., and Van Loon, A.: Validatie rekenregels voor waterverbruik hotels, KWR, Nieuwegein, The Netherlands, 2013a.

Pieterse-Quirijns, E. J., Beverloo, H., and Van Loon, A.: Validatie rekenregels voor waterverbruik kantoren, KWR, Nieuwegein, The Netherlands, 2013b.

Pieterse-Quirijns, E. J., Beverloo, H., Van Loon, A., and Kwakkel, M.: Validatie rekenregels voor waterverbruik zorginstellingen, KWR, Nieuwegein, The Netherlands, 2013c.

Rankin, R. and Rousseau, P. G.: Sanitary hot water consumption patterns in commercial and industrial sectors in South Africa: impact on heating system design, Energ. Convers. Manage., 47, 687-701, 2006.
Scheffer, W. J. H.: Het ontwerpen van sanitaire installaties, Misset uitgeverij bv, Arnhem, The Netherlands, 1994.

Van der Kooij, D., Veenendaal, H. R., and Scheffer, W. J. H.: Biofilm formation and multiplication of Legionella in a model warm water system with pipes of copper, stainless steel and cross-linked polyethylene, Water Res., 39, 2789-2798, 2005.

Vreeburg, J. H. G.: Discolouration in drinking water systems: A practical approach, Ph.D. thesis, Delft University of Technology, Delft, The Netherlands, 2007.

Werkgroep momentane waterverbruiken: maximum momentane waterverbruiken, Kiwa N.V., Nieuwegein. mededeling nr. 93, 1985. 